Al Qalam: Jurnal Ilmiah Keagamaan dan Kemasyarakatan https://jurnal.stiq-amuntai.ac.id/index.php/al-qalam P-ISSN: 1907-4174; E-ISSN: 2621-0681

\title{
PENGARUH ANIMISME: HILANGNYA KAHARINGAN DALAM PILIHAN AGAMA DI INDONESIA
}

\author{
Muhammad Sandi Rosyadi \\ Dosen Studi Agama-Agama, Fakultas, UIN Antasari Banjarmasin \\ sandirosyadi@uin-antasari.ac.id
}

\begin{abstract}
Abstrak
Beragama merupakan elemen penting dalam kehidupan seorang individu, sehingga kebebasan bergama haruslah dijamin oleh negara sebagai bagian dari Hak Asasi Manusia. Indonesia memberikan kebebasan bagi warganya untuk memeluk dan mempercayai agama maupun kepercayaan yang mereka yakini. Akan tetapi, Indonesia masih membatasi jumlah agama yang bisa dianut secara resmi oleh warganya. Pembatasan tersebut dapat terlihat dalam pilihan agama resmi di Indonesia yang hanya berjumlah 6 agama, meliputi islam, Kristen katolik, Kristen protestan, hindu, budha dan konghu chu. Disisi lain, banyak agama atau kepercayaan yang ada di masyarakat Indonesia tidak terakui oleh negara. Dalam artikel ini, penulis berpedapat bahwa hal ini terjadi akibat adanya standarisasi katagori agama yang terbelenggu oleh standar sebuah agama para pemikir barat. E.B Taylor sebagai tokoh antropologi agama klasik memberikan pengaruh besar terhadap pembatasan pengertian agama melalui teorinya tentang asal usul agama, hal ini berimbas pada pemahaman para pemikir agama bahwasanya animisme merupakan bentuk kepercayaan yang belum sempurna dan tidak bisa disebut sebagai sebuah agama. Kaharingan sebagai kepercayaan asli masyarakat Kalimantan menjadi bagian dari pembatasan pengertian agama ini. Sehingga kaharingan tidak bisa masuk kedalam agama yang diakui secara resmi oleh Indonesia.

Kata Kunci : Animisme, Agama, Dayak.Kaharingan
\end{abstract}

\section{PENDAHULUAN}

Indonesia merupakan negara multikultural yang mayoritas penduduknya beragama Islam, maka tidak mengherankan bila agama Islam menjadi agama utama di Indonesia. Selain agama Islam ada juga agama yang diakui oleh negara sebagai agama terdaftar, Kristen, Protestan, Hindu, Budha dan Konghucu. Namun masih banyak agama atau kepercayaan yang dianut oleh masyarakat

Al Qalam: Jurnal Ilmiah Keagamaan dan Kemasyarakatan

Vol. 14, No. 2, Juli-Desember 2020 
Muhammad Sandi Rosyadi : Pengaruh Animisme : Hilangnya Kaharingan Dalam Pilihan Agama di Indonesia

Indonesia yang belum diakomodasi atau diakui oleh pemerintah Indonesia, salah satunya adalah agama Dayak Kaharingan di Kalimantan.

Menariknya, apa yang terjadi terhadap agama lokal Kalimantan yaitu Kaharingan agama masyarakat Dayak, pemerintah melalui kementerian agama, melakukan sosialisasi dan pendekatan serta negosiasi dengan mereka untuk pindah dan di cap menjadi salah satu agama yang diakui oleh pemerintah Indonesia. Dalam kasus dayak Kaharingan, pemerintah menandainya sebagai bagian dari agama Hindu. Sehingga nama Dayak Kaharingan diganti menjadi agama Hindu Kaharingan untuk diakui oleh pemerintah Indonesia.

Bagi saya, ini bagian dari politisasi agama di Indonesia, yang tidak lepas dari peran agama dakwah besar atau agama dunia, yang menganggap segala sesuatu yang berhubungan dengan animisme, adalah kepercayaan yang dianggap sebagai "tradisi rakyat". , bukan sebagai agama. Hal tersebut merupakan akibat dari teori yang dikemukakan Taylor tentang animisme yang merupakan awal mula dari asal mula agama, sehingga di era modern ini animisme bukan lagi bagian dari agama, akan tetapi agama tauhid merupakan agama modern saat ini.

Pada artikel ini saya akan menjelaskan bagaimana kepercayaan masyarakat Dayak dapat dianggap sebagai bagian dari animisme, kemudian saya akan menjelaskan efek dari pemisahan animisme dan agama, seperti yang terjadi di Indonesia khususnya Kaharingan tidak dianggap oleh pemerintah Indonesia sebagai bagian dari dari agama yang sah, sehingga mereka harus diperbolehkan pindah ke salah satu agama yang diakui oleh pemerintah Indonesia.

\section{METODE PENELITIAN}

Dalam penelitian ini penulis menggunakan metode kualitatif deskriptif, jenis penelitian ini menggunakan data kualitatif yang kemudian dijabarkan secara deskriptif, sehingga penelitian ini menggambarkan secara baik dengan penjabaran panjang mengenai permasalahan yang terjadi, serta penyebab permasalahan kasus. Penggunaan metode ini menurut penulis adalah cara yang tepat dalam mencoba menjawab pertanyaan seputar fenomena kemasyarakatan dan keagamaan.

\section{HASIL DAN PEMBAHASAN}

\section{a. Kaharingan sebagai bagian dari animisme}

Kaharingan adalah sebutan formal untuk sistem kepercayaan Luangan, Maanyan, Ngaju dan ot Danum yang merupakan salah satu kelompok suku Dayak di Kalimantan. Kaharingan berasal dari akar kata "herring" yang berarti keberadaan diri, sumber atau vitalitas. Ada juga yang

Al Qalam: Jurnal Ilmiah Keagamaan dan Kemasyarakatan

Vol. 14, No. 2, Juli-Desember 2020 
mengatakan bahwa ikan haring berasal dari Parey herring yang artinya "padi yang tumbuh secara spontan"1. Ada juga yang berpendapat Kaharingan berarti "hidup", sumber kehidupan yang bersumber dari dewa ${ }^{2}$. Kaharingan adalah kepercayaan yang dianut oleh banyak orang Dayak, terkadang setiap kelompok atau wilayah Dayak Kaharingan memiliki jalannya masing-masing, namun Kaharingan di Kalimantan bagian utara tidak dapat dipisahkan dengan Kaharingan di Kalimantan bagian selatan, tetapi juga tidak dapat disamakan.

Sebagai kepercayaan, Kaharingan merupakan salah satu cara hidup masyarakat Dayak, namun bagi para antropolog, Kaharingan dikategorikan animisme. Karena kepercayaan dan ritual yang dilakukan oleh penganut Kaharingan, merupakan sesuatu yang dikonseptualisasikan oleh EB Taylor sebagai animisme yaitu kepercayaan masyarakat ras bawah, yang merupakan cikal bakal agama modern saat ini.

Pemikiran animisme bersumber dari pemikiran Taylor tentang kematian dan mimpi, dalam satu kasus, kehidupan dalam diri seseorang tampak terpisah dari tubuh fisik, di sisi lain, semacam hantu, atau gambar tampak mampu melakukan hal yang sama. Kedua hal ini dapat dipertanggungjawabkan jika kita membuat langkah berikutnya dan alami dalam logika dan menggabungkannya menjadi satu, menjadi gagasan tentang jiwa pribadi yang mencerminkan tubuh dan menjiwainya dari dalam ${ }^{3}$.

Taylor sendiri mengkategorikan animisme ke dalam dua bentuk, yang pertama tentang jiwa makhluk individu, yang mampu terus eksis setelah kematian atau kehancuran tubuh, yang kedua tentang roh lain yang naik ke pangkat dewa yang kuat. Makhluk spiritual dianggap mempengaruhi atau mengendalikan peristiwa dunia material, dan kehidupan manusia di sini dan di akhirat dan dianggap bahwa memegang hubungan dengan manusia, dan menerima kesenangan dan ketidaksenangan dari tindakan manusia, keyakinan akan keberadaan mereka mengarah secara alami, dan cepat atau lambat bisa dikatakan hampir pasti akan dikatakan pada penghormatan dan pendamaian yang aktif ${ }^{4}$.

\footnotetext{
1 Joseph A. Weinstock, "Kaharingan: Life and Death in Southern Borneo", Indonesian Religions in Transition, (1987), hlm. 71- 97

2 Martin Baier, "Perkembangan Agama Hindu Kaharingan: Agama Dayak Baru di Kalimantan Tengah", Anthropos, Bd. 102, H. 2. (2007), hlm.566-577

3 Daniel L. Pals "Memperkenalkan agama: bacaan dari para ahli teori klasik." (2009). p, 3

4 ibid. hal 11
}

Al Qalam: Jurnal Ilmiah Keagamaan dan Kemasyarakatan Vol. 14, No. 2, Juli-Desember 2020 
Kepercayaan Kaharingan dapat dikatakan sebagai tauhid, tetapi juga politeisme secara bersamaan $^{5}$, karena Kaharingan percaya pada satu tuhan, dewa yang menciptakan alam semesta dan semua makhluk hidup yang disebut hatala langih, maha tala dan lain sebagainya, tetapi ada roh dan dewa yang mengatur kehidupan manusia di hampir setiap bidang. Adapun di bidang pertanian, setiap penganut Kaharingan yang ingin memulai proses bercocok tanam, mereka meminta persetujuan kepada dewa petani, atau ingin membuka lahan baru dengan cara membakarnya, kemudian mereka meminta persetujuan kepada dewa api,

selain bahwa Kaharingan juga meyakini bahwa arwah orang mati masih berpengaruh dalam kehidupan mereka, karena mereka percaya bahwa arwah orang mati tidak langsung naik ke langit, tetapi tetap berada disekitar mereka, oleh karena itu mereka tetap melakukan upeti dengan semangat orang mati. Apalagi jika orang tersebut berjasa atau memiliki kedudukan yang tinggi di masyarakat, bisa jadi roh orang tersebut akan dianggap sebagai salah satu dewa, dikategorikan sebagai dewa yang berasal dari manusia, seperti legenda dewa yang sangat terkenal di masyarakat Dayak Kaharingan. tentang Panglima Burung dulunya ketika hidupnya adalah panglima besar dalam pertempuran untuk masyarakat Dayak.

Dengan demikian dapat disimpulkan bahwa kepercayaan Kaharingan yang dianut oleh masyarakat Dayak dapat dikategorikan animisme dalam teori Taylor, bukan hanya karena Taylor sendiri mengatakan: Orang Dayak Kalimantan tidak hanya menganggap manusia dan hewan memiliki prinsip hidup yang berjiwa, yang kepergiannya Dari tubuh menyebabkan penyakit dan akhirnya kematian, tetapi juga memberikan pada beras "semangat padi" atau "semangat padi" dan mereka mengadakan pesta untuk mempertahankan jiwa ini dengan aman, agar tanaman tidak membusuk $^{6}$. Tetapi juga animisme yang dikategorikan oleh Taylor sebagai percaya pada arwah orang mati tetap melanjutkan keberadaannya, seperti penganut Kaharingan yang meyakini bahwa orang mati masih ada disekitar mereka atau bahkan bisa menjadi dewa jika memiliki peran besar ketika masih hidup. hidup. Begitu pula pada kategori animisme yang mempercayai roh yang dapat mengatur dan mengontrol kehidupannya juga terdapat dalam kepercayaan Kaharingan. Yang meyakini bahwa setiap benda yang ada di muka bumi ini memiliki ketuhanan sehingga ketika ingin melakukan pekerjaan tertentu, harus meminta restu kepada ketuhanan yang bersangkutan dengan bidang tersebut.

\footnotetext{
5 Weinstock, "Kaharingan" hal 78

6 Pals, "memperkenalkan agama" hal 21
}

Al Qalam: Jurnal Ilmiah Keagamaan dan Kemasyarakatan Vol. 14, No. 2, Juli-Desember 2020 


\section{b. Pengaruh Teori Animisme}

Setelah kita mempercayai Kaharingan sebagai bagian dari animisme yang diangkat oleh Taylor, maka saya akan mencoba menjelaskan tentang pengaruh yang terjadi terhadap kepercayaan Kaharingan yang berlabel animisme. Yang Kaharingan anggap dikucilkan dari agama yang sah di Indonesia dan harus masuk salah satu agama yang diterima oleh pemerintah Indonesia, maka Kaharingan kini dicap sebagai bagian dari Hindu atau Hindu Kaharingan.

Ini dimulai dengan pemisahan Taylor yang dilakukan antara agama-agama ras yang lebih rendah sebagai bagian asli dan asli dari pertambahan dan transformasi karena kontak dengan orang asing yang beradab ${ }^{7}$. Atau bisa juga dikatakan pemisahan antara agama (animisme) dan agama modern (tauhid). Sehingga segala sesuatu yang memiliki unsur animisme tidak dianggap sebagai bagian dari agama.

Dimana kata "agama" sendiri adalah sesuatu yang berasal dari Kristen dan barat, seperti pendapat Richard king: Konsep 'agama' adalah produk dari proses diskursif spesifik budaya sejarah Kristen di Barat dan telah dipalsukan dalam wadah konflik dan interaksi antaragama ${ }^{8}$. Maka tidak mengherankan jika keyakinan yang ingin dipersepsikan sebagai agama, harus memiliki kesamaan dengan agama Kristen, tauhidnya, memiliki kitab suci dan lain sebagainya. Dan itu bagi saya juga merupakan pengaruh dari pemisahan modern antara agama dan animisme, dimana agama Kristen sebagai agama modern sebagai acuan utama dan animisme adalah sesuatu yang berbeda dengan agama modern. Seperti Michel Picard, dia berpendapat bahwa asumsi umum para sarjana Barat adalah bahwa agama-agama dunia ini harus memiliki kesamaan esensial dengan agama Kristen dalam hal penilaiannya: mereka diharapkan memiliki struktur formal dari doktrin tetap, bertumpu pada otoritas kanonik, menjadi ditegakkan oleh hierarki imamat, dan didukung oleh ibadah jemaat. Dalam hal ini, agama-agama dunia dianggap sebagai agama 'maju', berlawanan dengan agama yang lebih terlokalisasi, dan dianggap sebagai 'primitif atau animisme'?

Di Indonesia, agama diartikan sebagai "agama" yang menurut saya hanyalah perubahan kata dari bahasa Inggris ke bahasa Indonesia. Karena baik agama maupun "agama" sama-sama memiliki persyaratan khusus untuk menjadi bagiannya. Sesuatu yang bisa dikategorikan sebagai agama haruslah wahyu ketuhanan harus dicatat oleh seorang nabi dalam kitab suci, sistem hukum bagi

7 Edward B. Taylor, "pada batas-batas agama biadab", Jurnal Institut Antropologi Inggris Raya dan Irlandia, Vol. 21, (1892), hal. 298

8 Richard King, Orientalisme dan agama: teori pasca-kolonial, India dan Timur mistik, (New York: Routledge, 1999) hal 40

9 Michel Picard, "Pengenalan: Agama, Adat dan Pancasila", Politik Agama di Indonesia: Sinkretisme, Ortodoksi, dan Perselisihan Agama di Jawa dan Bali, (2011) hal 2

Al Qalam: Jurnal Ilmiah Keagamaan dan Kemasyarakatan

Vol. 14, No. 2, Juli-Desember 2020 
umat beriman, ibadah berjamaah, dan keyakinan pada Tuhan Yang Maha Esa ${ }^{10}$. Dengan kondisi tersebut, kemudian muncul pertanyaan seperti yang dipertanyakan oleh Rita Smith dan Susan Rodgers, bagaimana dengan orang yang belum beragama atau memiliki keyakinan lain, tetapi tidak memenuhi syarat sebagai "agama"? ${ }^{11}$ Seperti Kaharingan

Maka disinilah muncul masalah, masalah yang saya katakan sebagai akibat dari pemisahan antara keyakinan yang dikatakan sebagai "animisme" dengan keyakinan yang disebut "agama modern". Yang diluar kepercayaan agama modern tidak diakui, bahkan ironisnya, sebagaimana terjadi dengan Kaharingan memberikan label kepercayaan seperti Kaharingan untuk menjadi bagian dari salah satu agama arus utama di Indonesia, dalam hal Kaharingan adalah Hindu ${ }^{12}$.

Kesimpulan dari penjelasan dan argumentasi yang telah saya berikan, pemisahan antara animisme dan agama modern bermuara pada munculnya kata dan definisi "agama” yang mengacu pada agama kristen dapat dikatakan dikategorikan sebagai keyakinan agama. Hal ini berdampak pula pada pemahaman "agama" di Indonesia yang menuntut semua keyakinan yang ingin diakui oleh Negara, harus dikualifikasikan sebagai agama modern. Hal ini berdampak besar pada keyakinan yang masih menganut animisme dan tidak memenuhi persyaratan tersebut, tidak akan diakui oleh pemerintah Indonesia dan harus berpindah agama seperti Kaharingan menjadi salah satu agama arus utama di Indonesia, dan hal ini terjadi pada Kaharingan yang menjadi Hindu Kaharingan.

\section{c. Belajar dari Kasus Kaharingan}

Jika kita melihat apa yang terjadi pada Kaharingan sebagai kepercayaan yang dianggap animisme, belajar juga dari dampak pemikiran tersebut. Kemudian kita harus memikirkan kembali tentang teori animisme yang dikemukakan oleh E B. Taylor, di mana ada kesalahpahaman tentang apa yang dia sebut animisme adalah sesuatu di luar agama modern, sesuatu yang hanya dipraktikkan oleh masyarakat primitif, dan lain sebagainya. Karena kepercayaan tersebut masih dianut oleh banyak komunitas masyarakat saat ini dan diyakini sebagai cara hidup dan mengabaikan atau bahkan menggabungkan sistem kepercayaan yang ditawarkan oleh agama-agama modern.

Seperti yang ditulis oleh Nurit-Bird-David "animism revisited", dia berpendapat bahwa ada kesalahpahaman para sarjana barat tentang animisme. Dalam artikelnya dia menjelaskan bagaimana

\footnotetext{
10 ibid, hal 3

11 Rita S Kipp dan Susan Rodgers, "Introduction, Indonesian Religions in Society”, Indonesian Religions in Transition, (1987), hal 1-31

12 Gerard Persoon, "Kelompok Terisolasi atau Masyarakat Adat: Indonesia dan Wacana Internasional", Bijdragen tot de Taal-, Land-en Volkenkunde, Vol. 154, No.2, Globalization, Localization and Indonesia, (1998), hal 293
}

Al Qalam: Jurnal Ilmiah Keagamaan dan Kemasyarakatan Vol. 14, No. 2, Juli-Desember 2020 
orang-orang Nayaka dari India memahami konsep kepribadian dalam kehidupan mereka, seperti konsep devaru sebagai sesuatu yang dianggap "orang super". Mereka memahami konsep berbagi kepada semua makhluk termasuk roh dan manusia super, karena mereka percaya pada konsep "wean" atau kesatuan dengan segala sesuatu termasuk lingkungan, dengan manifestasi batu, atau hewan dan lain sebagainya ${ }^{13}$.

Di sinilah muncul kesalahpahaman, dimana sarjana barat yang mengacu pada teori Taylor menganggap apa yang dilakukan oleh orang-orang Nayaka dari India sebagai kategori animisme, sedangkan yang mereka lakukan adalah sesuatu kepercayaan untuk dibagikan dan dihormati untuk orang lain, termasuk semangat masyarakat. di hadapan mereka, lingkungan dan alam sekitar ${ }^{14}$

Seperti halnya Samsul Maarif dalam tulisannya "Muslim in animistic", ia "menawarkan" konsep animisme yang berbeda seperti yang kita ketahui, dilakukan oleh masyarakat Ammatoans dalam hubungannya dengan hutan dan lingkungan. Mereka menganggap bahwa hutan dan segala isinya adalah sumber kesejahteraan dan harus dihormati manusia, mereka menjaga hutan dari pemanfaatan manusia, seperti tumbuhan, hewan, buah atau kayu, demi kelestarian hutannya. Ini mungkin dianggap animisme, tapi nyatanya apa yang dilakukan Ammatoa tidak bertentangan dengan ajaran Alquran sebagai kitab suci umat Islam yang juga mereka anut ${ }^{15}$.

Kesimpulannya, dari kedua cendekiawan brilian ini, mereka sama menunjukkan bahwa persepsi animisme yang sering kita anggap sebagai sesuatu di luar agama, atau sesuatu yang bukan bagian dari suatu agama, atau bahkan kafir, adalah sesuatu yang salah. Mereka membuktikan bahwa animisme bukanlah sesuatu yang harus dimaknai sebagaimana ditafsirkan oleh Taylor, karena banyak orang yang menganut kepercayaan yang dianggap sebagai "animisme" tidak bertentangan dengan ajaran agama dan dengan pemahaman atau tujuan yang berbeda. Oleh karena itu pembenaran kepercayaan yang dianggap animisme seperti Kaharingan harus dihilangkan dan diubah dengan cara pandang baru kepada apa yang disebut animisme, karena pembenarannya mungkin saja berdampak seperti yang terjadi dengan Kaharingan dan lebih banyak lagi sistem kepercayaan di Indonesia bahkan di dunia yang tidak mendapat tempat dan pengakuan dari masyarakat. , dan pemerintah

13 Nurit Bird-David, "'Animisme' Revisited: Kepribadian, Lingkungan, dan Epistemologi Relasional", Antropologi Saat Ini, vol. 40, tidak. S1 (Feb 1999), hlm.67-91.

14 ibid

15 Samsul Maarif, "Menjadi Muslim dengan Cara Animistik”, Al-Jami'ah: Jurnal Kajian Islam, Vol. 52, tidak. 1 (2014), hlm.149-174

Al Qalam: Jurnal Ilmiah Keagamaan dan Kemasyarakatan

Vol. 14, No. 2, Juli-Desember 2020 


\section{KESIMPULAN}

Di awal artikel saya, saya menggambarkan kepercayaan Kaharingan masyarakat Dayak di Kalimantan sebagai kepercayaan yang dikategorikan oleh E B. Taylor sebagai animisme, berdampak pada Kaharingan sebagai sistem kepercayaan sebagian kecil masyarakat Indonesia. Karena adanya pemisahan antara animisme dan agama modern oleh E B. Taylor berdampak pada munculnya Agama oleh para sarjana barat yang mengacu pada Kristen, yang merupakan bagian dari agama modern yang membuat kepercayaan dengan sistem berbeda tidak dapat disebut sebagai agama.

Hal ini juga terjadi di Indonesia dengan nama yang berbeda "agama" yang juga mengacu pada persyaratan agama utama dunia, yang percaya pada satu tuhan, memiliki kitab suci, dan memiliki nabi dan sebagainya. Sehingga menjadikan sistem kepercayaan yang tidak memenuhi persyaratan tersebut dikecualikan dari "agama" di Indonesia. Ironisnya pemerintah mengubah penganut kepercayaan tersebut menjadi salah satu agama yang diakui pemerintah, seperti yang terjadi pada Kaharingan yang menjadi Hindu Kaharingan.

Maka saya berpendapat ada kekurangan pada teori Taylor tentang animisme sebagai sesuatu yang harus dipisahkan oleh agama, karena berdampak negatif terhadap kepercayaan yang memiliki sistem animisme. Padahal banyak sistem kepercayaan masyarakat adat yang berbeda yang mempercayai sesuatu yang dikategorikan animisme namun dengan konsep yang berbeda, sehingga generalisasi sistem kepercayaan masyarakat adat seperti Kaharingan dianggap animisme yang bukan merupakan sistem kepercayaan yang benar dan tidak sesuai. dengan ajaran agama modern adalah kesalahan yang fatal.

\section{DAFTAR PUSTAKA}

A. Weinstock, Joseph, “Kaharingan: Hidup dan Mati di Kalimantan Selatan”, Indonesian Religions in Transition, 1987

Baier, Martin, "Perkembangan Agama Hindu Kaharingan: Agama Dayak Baru di Kalimantan Tengah", Anthropos, Bd. 102, H. 2. 2007

Bird-David, Nurit, "'Animisme' Revisited: Kepribadian, Lingkungan, dan Epistemologi Relasional", Antropologi Saat Ini, vol. 40, tidak. S1, Feb 1999

B. Taylor, Edward, "di batas agama biadab", Jurnal Institut Antropologi Inggris Raya dan Irlandia, Vol. 21, 1892

Al Qalam: Jurnal Ilmiah Keagamaan dan Kemasyarakatan

Vol. 14, No. 2, Juli-Desember 2020 
Muhammad Sandi Rosyadi : Pengaruh Animisme : Hilangnya Kaharingan Dalam Pilihan Agama di Indonesia

Raja, Richard, Orientalisme dan Agama: teori pasca-kolonial, India dan Timur mistik, New York: Routledge, 1999

Maarif, Samsul, "Menjadi Muslim dengan Cara Animistik", Al-Jami'ah: Jurnal Kajian Islam, Vol. 52, tidak. 1, 2014

Pals, Daniel L. "Memperkenalkan agama: bacaan dari ahli teori klasik." 2009

Persoon, Gerard, "Kelompok Terisolasi atau Masyarakat Adat: Indonesia dan Wacana Internasional“, Bijdragen tot de Taal-, Land- en Volkenkunde, Vol. 154, No. 2, Globalisasi, Lokalisasi dan Indonesia, 1998

Picard, Michel, "Pengantar: Agama, Adat dan Pancasila", Politik Agama di Indonesia: Sinkretisme, Ortodoksi, dan Perselisihan Agama di Jawa dan Bali, 2011

S.Kipp , Rita dan Susan Rodgers, "Introduction, Indonesian Religions in Society", Indonesian Religions in Transition, 1987

Al Qalam: Jurnal Ilmiah Keagamaan dan Kemasyarakatan

Vol. 14, No. 2, Juli-Desember 2020 